Spring 2005

\title{
Guestworkers and Exploitation
}

\author{
Robert Mayer \\ Loyola University Chicago, rmayer@luc.edu
}

Follow this and additional works at: https://ecommons.luc.edu/politicalscience_facpubs

Part of the Political Science Commons

\section{Recommended Citation}

Robert Mayer (2005). Guestworkers and Exploitation. The Review of Politics, 67, pp 311-334. doi:10.1017/ S0034670500033532.

This Article is brought to you for free and open access by the Faculty Publications and Other Works by Department at Loyola eCommons. It has been accepted for inclusion in Political Science: Faculty Publications and Other Works by an authorized administrator of Loyola eCommons. For more information, please contact ecommons@luc.edu. (c) (i) $\Theta$

This work is licensed under a Creative Commons Attribution-Noncommercial-No Derivative Works 3.0 License. (c) University of Notre Dame, 2005. 


\section{Guestworkers and Exploitation}

\section{Robert Mayer}

Are guestworker programs exploitative? Egalitarian and neoclassical theories of exploitation agree that they always are. But these judgments are too indiscriminate. Privileged guests are the exception, and the exception points toward a more sensitive standard for identifying exploitation. This more sensitive standard, the sufficiency theory of exploitation, is used to analyze several guestworker programs. Even when guestworker programs are exploitative, it is argued that the unfairness should be tolerated if the exploitation is modest, not severe, and if the most likely nonexploitative alternative worsens the plight of the disadvantaged.

On January 7, 2004, President George W. Bush proposed that the United States create a guestworker program as a way to channel the flow of illegal immigration into the country. ${ }^{1}$ Foreign workers and undocumented immigrants would be granted legal status on temporary visas to work in designated sectors of the economy where there is a domestic labor shortage. The visas would be renewable every three years but not indefinitely, and the guestworkers and any dependents they bring would not be eligible for many government benefits or set automatically on the path to naturalization. Like other host countries, the United States would be offering a trade-off to prospective guests: accept temporary admission into a lucrative labor market in exchange for some of the privileges other residents of the jurisdiction enjoy.

If the Bush proposal is enacted, there is no doubt that many foreign and undocumented workers will take the offer. But their consent does not necessarily ensure that the offer is fair. Some critics charge that guestworker programs are unjust because they exploit or take unfair advantage of foreign labor. The host country gains at the expense of its guests, who do the dirty work of the society in exchange for low wages and second-class status. The fact that the guests do the work willingly does not remove the taint of unfairness, for it is wrong to take advantage of vulnerable people. Wealthy countries must therefore offer something better, or they should make no offer at all. If they will not treat as equals the newcomers

1. "Fact Sheet: Fair and Secure Immigration Reform," Press Release by the Office of the Press Secretary, 7 January 2004. 
who do their dirty work, justice demands that hosts do the dirty work themselves, offering a good wage that will entice citizens to get the job done.

Michael Walzer has set forth the most famous egalitarian version of this argument, ${ }^{2}$ but guestworker programs also appear to be exploitative from a purely capitalist standpoint. Daniel Attas has shown that guestworker programs are unfair according to neoclassical theory because they restrict competition and result in deviations from the equilibrium price for labor. ${ }^{3}$ This is a rare case where left and right converge, and we might therefore conclude that guestworker programs are hopelessly unfair and exploitative. However advantageous the offers seem to guests or hosts, decent governments should not make them.

But in this article I will show that neither the egalitarian nor the neoclassical critique of guestworker programs is convincing. Such programs are not invariably exploitative, as the critics maintain. We must therefore be more discriminating in our judgments, and we need a standard of exploitation that is more discriminating too. The egalitarian and neoclassical theories of exploitation sometimes miss the mark and clash with intuitions about what seems like taking unfair advantage of others. A better alternative is the sufficiency standard, as I call it, which judges transactions from the standpoint of those who have enough. Such agents are not exploitable, and if they would accept an offer it cannot be deemed exploitative. On this standard some guestworker programs do not seem unfair and so are morally acceptable. Others are unjust, but unfairness by itself is not the only relevant consideration in assessing these programs. Sometimes the moral force of the injustice is weak and can be overridden by the transaction's good consequences, especially for guests. Then we ought to tolerate guestworker programs, even when they are exploitative. In tolerating such programs our hands do get a little dirty, but the moral costs of the dirt are less than the price foreign labor pays for the purist policy. There is such a thing as acceptable exploitation, in other words, and the Bush administration proposal may fall within that category.

My argument unfolds in five steps. First, I show why the egalitarian and neoclassical criticisms of guestworker programs fail. Next, I set forth the alternative sufficiency standard of exploitation. In the third section I assess two classic guestworker programs accord-

2. Michael Walzer, Spheres of Justice: A Defense of Pluralism and Equality (New York: Basic Books, 1983), pp. 52-63.

3. Daniel Attas, "The Case of Guest Workers: Exploitation, Citizenship and Economic Rights," Res Publica 6/1 (2000): 73-92. 
ing to this standard. The fourth part examines the moral force of exploitation claims and determines when good consequences can outweigh the unfairness of guestworker transactions. The last section concludes.

\section{The Problem of Privileged Guests}

Although the concept of exploitation is especially associated with Marxian theory, capitalist economics has a theory of exploitation too. According to the neoclassical standard, imperfect competition makes it possible for some agents to take unfair advantage of others. ${ }^{4}$ Exploiters have market power, which permits them to dictate price to the disadvantaged. The latter do not get the equilibrium price, which is set by perfect competition. Exploiters thus gain at their expense by paying less or receiving more than would be possible if competition was perfect. Monopoly is the classic example: for want of competition, monopolists are in an excellent position to take unfair advantage of dependent customers by charging exorbitant prices.

Attas nicely shows that if we adopt the neoclassical standard of exploitation, guestworker programs must be deemed exploitative. These programs typically restrict foreign labor

to employment in a particular industry, sector or, sometimes, even employer. Hence, in so far as this conditional force creates effective monoposonies that skew wages and make the exchange unequal, it appears that not only are guest workers exploited, but also that their exploitation may be as acute as that of slaves when their freedom of exchange is restricted to dealing with one possible employer only. ${ }^{5}$

Guestworkers do not get the equilibrium price for their labor because they are consigned to certain types of jobs and prevented from competing freely in the host labor market. In the sectors where they do work, "the equilibrium price without their presence would be significantly higher" since domestic labor will not work for the low wages paid to guests. ${ }^{6}$ Domestic labor and capital therefore gain at the expense of guestworkers by earning more than they would if no restrictions were placed on the newcomers. If competition was free, the guests could compete for the better paid jobs of native work-

4. For examples of the neoclassical theory of exploitation see A. C. Pigou, The Economics of Welfare (London: Macmillan, 1932), pp. 549-71; and David Miller, "Exploitation in the Market," in Modern Theories of Exploitation, ed. Andrew Reeve (London: Sage Publications, 1987), pp. 149-65.

5. Attas, "The Case of Guest Workers," p. 78.

6. Ibid., p. 79. 
ers. Fewer guests would then be available to do the dirty work, so they would have to be paid more. In turn the natives would face increased competition, and that will drive down their wages. But the whole point of guestworker programs is to restrict competition, so that natives gain at the expense of guests. These programs exist precisely in order to exploit, the critics charge.

According to Attas, the unfairness of guestworker programs is economic, not political. Guestworkers receive less than the equilibrium price for their labor, but the denial of citizenship to them is not necessarily unfair. Current members have broad discretion to grant or withhold political membership because they possess "the right to collective self-determination; the right of the community to shape itself, its character, the production of social goods and their maintenance and distribution." 7 Fellow citizens must exhibit loyalty, "but in the absence of any such indications, guest workers have no special claim to citizenship." ${ }^{\prime}$ Thus they need not be set on the path to naturalization when they are admitted into the jurisdiction of the state. But Attas insists that guestworkers must "be granted full equal membership at least with respect to their role in the economy." ${ }^{\prime 9}$ Above all, their basic human right to freedom of occupation must be scrupulously respected. Guestworkers must be free to seek work where they can find it and to compete with native workers. "This might be all that is needed to expel the spectre of exploitation. Were guest workers to enjoy the same economic rights as local workers, and particularly the freedom of occupational choice, then the cause of unequal exchange would be removed." 10 Exploitation would be abolished.

Attas's position is explicitly contrasted with the view of Michael Walzer, who argues from an egalitarian standpoint. For Walzer the injustice of guestworker programs is fundamentally political: guestworkers are only admitted into the jurisdiction of the state as second-class members, and because they are second-class members it is easy to exploit them economically.

As a group, [guestworkers] constitute a disenfranchised class. They are typically an exploited or oppressed class as well, and they are exploited or oppressed at least in part because they are disenfranchised, incapable of organizing effectively for self-defense. Their material condition is unlikely to be improved except by altering their political status. Indeed, the purpose 
of their status is to prevent them from improving their condition; for if they could do that, they would soon be like domestic workers, unwilling to take on hard and degrading work or accept low rates of pay. ${ }^{11}$

Guestworkers will not be allowed to compete freely, as Attas desires, as long as they are not political equals. But guestworkers cannot become political equals until we stop treating them as guests.

Although Walzer rarely uses the language of exploitation to frame his critique, it is clear from the text that the injustice of guestworker programs results from host countries taking unfair advantage of their guests. ${ }^{12}$ They drive a hard bargain, trading admission for an entitlement all other long-term residents enjoy-political membership. The transaction results in inequality, but this violates the egalitarian standard of exploitation Walzer adopts. When some accept less than an equal share in order to avoid a worse outcome, they are exploited-even if the choice is made in a competitive market.

Though Walzer describes a "complex" egalitarianism in Spheres of Justice, his argument against guestworker laws is in fact an example of what he calls "simple equality" or equal outcomes. ${ }^{13}$ All residents deserve political membership as compensation for the imposition of subjection; hence any who have been relegated to a second-class status are treated unfairly. "Men and women are either subject to the state's authority, or they are not; and if they are subject, they must be given a say, and ultimately an equal say, in what that authority does." ${ }^{14}$ Outcomes must be equal, even if some outsiders might consent to less in order to gain admission. Citizenship is an inalienable entitlement of (prolonged) residency, at least in modern democratic nations, and thus no agreement to yield the entitlement can be valid:

Democratic citizens, then, have a choice: if they want to bring in new workers, they must be prepared to enlarge their own membership; if they are unwilling to accept new members, they must find ways within the limits of the domestic labor market to get socially necessary work done. And those are their only choices. ${ }^{15}$

11. Walzer, Spheres of Justice, p. 59.

12. On Walzer's idea of dominance as a concept of exploitation see Robert Mayer, "A Walzerian Theory of Exploitation," Polity 34 (2002): 337-54.

13. On the simple egalitarian impulse in Walzer's theory see Robert Mayer, "Michael Walzer, Industrial Democracy and Complex Equality," Political Theory 29 (2001): 237-61.

14. Walzer, Spheres of Justice, p. 61.

15. Ibid., p. 61. 
Walzer is not a Marxist, but the simple-egalitarian standard of exploitation implied by his critique of guestworker programs is similar to the standard adopted by neomarxian exploitation theory. If one would be better off taking an equal share than accepting what is offered, neomarxian theory holds, that offer is exploitative..$^{16}$ Hence any transfer of surplus from labor to capital is exploitation, no matter how well off the workers are in absolute terms. Any deviation from equal shares is unfair. Marxists argue that no one can legitimately make a profit off others, and for the same egalitarian reason Walzer insists that no nation can legitimately buy the political rights of resident aliens.

When it comes to guestworker laws Walzer is a simple egalitarian, but his complex-egalitarian theory warns us to be skeptical about equalizing outcomes. And in a footnote to his argument Walzer identifies an exception that undercuts his sweeping rejection of guestworker programs:

It has been suggested to me that this argument doesn't plausibly apply to privileged guests: technical advisors, visiting professors, and so on. I concede the point, though I'm not sure just how to describe the category of "guest workers" so as to exclude these others. ${ }^{17}$

Walzer goes on to dismiss the exception as unimportant, but in fact this case points to a clash between the egalitarian standard of exploitation and intuitions about what counts as taking unfair advantage of others. Unequal outcomes are not always unfair, even when it comes to distributing political membership in democratic societies.

Consider a guestworker program designed to attract skilled foreign labor on temporary contracts. The workers come for several years and are employed in sectors of the economy where there is a shortage of skilled labor. They are paid good wages, though perhaps less than domestic workers can command, but they are not set on the path to naturalization and are denied certain government benefits. The idea is not hypothetical: many such programs exist. The American $\mathrm{H}-1 \mathrm{~B}$ visa program is an example. ${ }^{18}$ It attracts engineers and hi-tech workers from other lands, especially South Asia. The program grew rapidly during the full-employment economy of the late 1990s, but the number of visas has recently been cut. Since

16. For an influential example of neomarxian exploitation theory see John Roemer, Free to Lose: An Introduction to Marxist Economic Philosophy (Cambridge, MA: Harvard University Press, 1988).

17. Walzer, Spheres of Justice, p. 60.

18. Matthew Heller, "Companies Trying to Hire Foreign Professionals Face a Lower Cap on Visas," Workforce Management 83/2 (2004): 64-65. 
the 1970s Saudi Arabia has also recruited highly skilled workers from developed nations on a contract basis, without the prospect of naturalization.

These are guestworker programs, too, but the transaction does not seem obviously exploitative. Admission is granted on a secondclass basis, but the workers are well compensated and they cannot plausibly be described as desperate. They have good options, and so it does not seem possible that anyone could take advantage of them. They make a choice, working abroad for good money but only on a temporary basis. How could the transaction be unfair? The hosts do not appear to gain at their expense.

The objection applies as well to the neoclassical argument. Privileged guests are frequently sponsored by a particular employer, and the guests are tied to this job. They lack freedom of occupation, but it is still hard to view them as exploited. The restriction may reduce their incomes because it prevents these skilled guests from applying for work elsewhere, but failure to maximize gains hardly seems like proof of exploitation. The host employers must compete for their skills in the international labor market and offer a good salary. These guests are clearly not sweatshop workers, who may lack decent options. If the pay is good and the workers have alternatives, it does not seem unfair to ask them to yield their (alleged) right to freedom of occupation in exchange for admission. After all, not all rights are inalienable. Some can be sold if the price is right.

With regard to guestworker programs, both egalitarian and neoclassical exploitation theory are too sweeping and indiscriminate in their judgments. They both claim that guestworker transactions are always unfair to the guests, but that is not so. Privileged guests do not seem exploited, even when they forego the rights to freedom of occupation or naturalization. The host countries do not take unfair advantage of them. But if that intuition is correct, it suggests that we need a different and more sensitive standard of exploitation. Neither unequal outcomes nor deviations from the equilibrium price are proof that exploitation has occurred. A different calculation is required to determine when taking advantage becomes unfair. 


\section{The Sufficiency Standard}

Exploitation is a process of expanding inequality. ${ }^{19}$ Exploiters start with more and use that advantage to gain at the expense of the disadvantaged party. Consider the classic Marxian example: capitalists begin with more than propertyless workers and exploit this advantage to extract surplus value from labor. They get more because they start with more, and at the end of the transaction the advantaged party is in an even better position to exploit once again.

Exploitative transactions begin with either an offer or a threat. Threats reduce our options while offers expand them. ${ }^{20}$ Exploitative threats are directly coercive; taking advantage in this way is called extortion. But exploitative offers also depend on coercion to succeed, even though the offer itself is not coercive. The exploiter's offer increases the exploitable agent's options, but nonexploitative options are unavailable due to the coercive power of the state, which protects the existing distribution of assets. The exploiter does not have to coerce in order to take advantage because another agent is enforcing the rules of the game, which disadvantage the exploitable party. ${ }^{21}$ In guestworker transactions, for example, host employers are able to exploit foreign labor because the host government is using its coercive power to block other options, such as permanent residency with equal rights. The guests are not forced to come by the hosts, but they are forced to choose from a constrained set of options, the best of which may result in others gaining at their expense.

By definition exploiters gain when they take advantage, but it is also true that the disadvantaged party frequently gains from an exploitative exchange. Without the jobs capital offers, labor might starve. Being exploited, then, is usually better than the alternative. That is in fact why exploitation works. Exploitative exchanges are typically mutually advantageous. ${ }^{22}$ Both gain from the trade, but the gains are disproportionate. This is why these transactions are considered unfair.

19. On the concept of exploitation see Robert Goodin, "Exploiting a Situation and Exploiting a Person," in Modern Theories of Exploitation, pp. 166-200; Alan Wertheimer, Exploitation (Princeton: Princeton University Press, 1996); and Ruth Sample, Exploitation: What It Is and Why It's Wrong (Rowman and Littlefield, 2003).

20. On exploitative threats and offers see Michael Gorr, Coercion, Freedom and Exploitation (New York: Peter Lang, 1989), pp. 147-65.

21. On the role of coercion in exploitative offers see Alan Carling, "Exploitation, Extortion and Oppression," Political Studies 35 (1987): 173-88.

22. On mutually advantageous exploitation see Wertheimer, Exploitation, pp. 13-24. 
Every theory of exploitation implies an idea of the just price. Exploited parties do not receive the just price for what they offer; the exploiters cheat them, whether wittingly or not. But there are different ways to calculate the just price. That is why there are different theories of exploitation. In neomarxian theory equal shares is the standard of justice; hence any transfer of surplus is exploitative or unfair. In neoclassical theory the equilibrium price is the just price. The price monopolists can command is unfair because customers are at their mercy.

But the example of privileged guests demonstrates that neither of these standards is satisfactory. Skilled contract workers may not get the equilibrium price for their labor, since competition is constrained, but they do not seem to be exploited. These workers also do not get equal citizenship - the egalitarian just price for the burden of subjection-but again it is hard to view them as exploited. They seem to get a fair price for what they offer, and so there is no gain at their expense.

But why is this so? The answer, I think, is that they begin with enough. They earn decent wages at home and have options; they are not driven by necessity. If they choose to work abroad temporarily, yielding certain rights in exchange for better pay and adventure, the transaction seems fair because these guests negotiate from a position of sufficiency. While they have less than the host country and their prospective employers, they have enough, and that circumstance makes them unexploitable. You cannot take advantage of someone who has enough, for then there is no vulnerability to exploit. Enjoying sufficiency is the best defense against exploitation..$^{23}$

If this is correct, exploitable agents must not have enough of some relevant asset. They experience insufficiency, and that is why they accept exploitative offers. They are willing to get less than the just price because the alternative is still worse. Exploitable agents choose in a context of insufficiency, and this motivates them to accept their best offer, even if it is poor, in order to make the best of a bad lot. For them being exploited is usually the lesser evil.

Not all exploitable agents are exploited, however. If the advantaged party does not press the advantage, the exchange may be fair. Consider an example. Unemployed workers who have exhausted their benefits are extremely vulnerable where

23. The exploitable insufficiency is not always financial. Affluent people who are emotionally needy can be exploited by someone with less income. These vulnerable individuals make enough money but still lack sufficient well-being and so can be taken advantage of. 
there is a glut of labor. Unscrupulous employers could offer them a mere pittance for sweatshop work. But if an employer with a heart of gold offers these vulnerable workers high wages and good conditions, we would not describe the transaction as exploitative. Though the unemployed do not begin with enough in either case, in the latter exchange the employer does not gain at the employees' expense. No exploitation has occurred.

We only think that agents are exploited if they gain too little from the transaction or pay too much for what they do gain. When jobs are scarce people tend to take their first offer, but if the wage is very low and the work is hard, we think the employees gain less than they should. Sweatshop jobs do not pay enough, even when they pay more than the alternatives. It is the insufficiency of the compensation that renders these jobs exploitative. The employer offers more than competitors but less than is sufficient.

But how do we know how much is enough? For an answer we look to an agent who starts above the threshold of sufficiency. ${ }^{24}$ If one who has enough might plausibly take the offer, that offer is not exploitative. After all, someone with enough at the start is unexploitable; hence that agent cannot be exploited. This agent becomes the standard by which to assess transactions. For example, if someone who already earns a secure living wage switches jobs, we can assume that a just price was paid for labor. But if that individual would spurn the offer as insufficient, the offer is exploitative. One party is trying to gain at the expense of the other by offering less than the just price.

The sufficiency standard requires us to determine how much is enough in any given case. That may seem like a hopeless task, for sufficiency is culturally and historically relative. What is enough in one time or place may not be enough in another. And even within any given culture, there is usually disagreement about exactly how much is enough. It may therefore seem that the sufficiency standard is too subjective to settle our disputes. But I think this is false. In fact modern societies constantly engage in threshold setting about the level of sufficiency, and there is usually a broad consensus about how much is enough. We set

24. The proper benchmark is a person (1) just above the threshold of sufficiency and (2) for whom sufficiency is guaranteed. The latter circumstance is crucial and assumed in all of my examples. Someone at the level of sufficiency can still be exploited if that sufficiency is insecure. The nonexploitative standard is thus an individual who is guaranteed sufficiency if she rejects an offer made by another agent. 
poverty lines, minimum and living wage rates, overtime rules, housing standards, and so forth. All of these are measures of sufficiency in a given time and place. We may not agree to the dollar or euro about how much income is enough, but precise measures like that are unnecessary to assess exploitative transactions. I do not have to know exactly how much is enough to know that well-paid American engineers who take three-year contracts in Saudi Arabia are not exploited, even if the Saudis refuse to naturalize them. They start with enough and so cannot be exploited. The prospect of exploitation only arises for those who are not guaranteed a living wage, and within any given culture members have a rough, intersubjective idea of what that wage is. ${ }^{25}$

My claim is that the sufficiency standard best matches intuitions about which transactions are exploitative. ${ }^{26}$ When we say people have been taken unfair advantage of, I believe, we do so because we think that (1) they will not have enough if they refuse the offer but (2) gain less from the transaction or pay more than would one who begins with enough.

Because it takes sufficiency as the benchmark for assessing transactions, this standard could be classified as a liberal egalitarian theory of exploitation. Its nonexploitative ideal is a society in which everyone begins with at least enough. Inequalities above that threshold are permissible, but priority should be placed on reducing insufficiency. ${ }^{27}$ As I will show in the fourth section, this priority has interesting implications for the choice between exploitative and nonexploitative policies.

Before that question is broached, however, I will apply the sufficiency standard to two classic guestworker programs. As we shall see, given this standard the exploitativeness of guestworker arrangements is often mixed: while there is usually a degree of ex-

25. A sufficiency wage is at least a living wage. On the theory and practice of the living wage see Robert Pollin and Stephanie Luce, The Living Wage: Building a Fair Economy (New York: New Press, 1998).

26. On intuition as the test of adequacy in contemporary moral theory see Will Kymlicka, Contemporary Political Philosophy: An Introduction (Oxford: Clarendon Press, 1990), pp. 5-8.

27. Within the liberal egalitarian camp, the sufficiency standard most closely matches Richard Arneson's prioritarian theory, which tilts in favor of those who are badly off. See Richard Arneson, "Luck Egalitarianism and Prioritarianism," Ethics 110 (2000): 339-49. A related theory is Martha Nussbaum's capabilities approach, which aims to raise as many people as possible above a threshold of well-being. See Martha Nussbaum, Women and Human Development: The Capabilities Approach (Cambridge: Cambridge University Press, 2000). 
ploitation in programs that recruit unskilled labor, even temporary workers without special skills sometimes appear to gain a just price for their labor.

\section{From Theory to Practice}

Highly skilled guestworkers are not typically exploited, but most guestworkers are not highly skilled. This increases the chance that they will be exploited, for semi-skilled or unskilled workers will usually begin with less and will likely get less as well. This is also true in the domestic labor market. The sufficiency standard therefore points us toward the bottom half of the occupational structure as the place where exploitation is more likely to occur. By contrast, Marxian exploitation theory finds exploitation wherever profits are made from labor, skilled or unskilled, while neoclassical exploitation theory sees no exploitation at the bottom as long as competition is robust. The sufficiency standard occupies a middle position between the two.

In deciding whether a guestworker contract is exploitative from the sufficiency standpoint, we must consider what a typical person above the threshold of sufficiency from the labor-exporting nation might choose to do. This is the appropriate counterfactual benchmark because prospective guestworkers who refuse the host-nation offer remain at home. We judge their exploitability by whether they will have enough if they do not migrate, and we judge exploitable workers to be exploited if they gain less than one with enough at home would likely accept. The proper benchmark, then, is a potential guest who starts with enough. We ask whether that person would accept a temporary job in another land at the level of compensation being offered.

Let us begin with the paradigmatic guestworker program: the West German recruitment of Turkish workers during the $1960 \mathrm{~s}^{28}$ In her fine book Exporting Workers, Suzanne Paine shows that the conventional assumption - that guestworkers come from the poorest strata of society - is mistaken for this case. In fact, the Turkish "migrants tended to be better off than their fellow countrymen." 29 They were on average better educated and more skilled than Turks

28. On the history of guestworker programs see Cindy Hahamovitch, "Creating Perfect Immigrants: Guestworkers of the World in Historical Perspective," Labor History 44 (2003): 69-94. On the origin, development, and termination of the German Gastarbeiter program see Ulrich Herbert, A History of Foreign Labor in Germany, 1880-1980 (Ann Arbor: University of Michigan Press, 1990), pp. 209-54.

29. Suzanne Paine, Exporting Workers: The Turkish Case (London: Cambridge University Press, 1974), pp. 79-86. 
who remained at home. They were less likely to be unemployed and tended to earn higher incomes before emigrating. Indeed, the income of the average Turkish worker was one-third less than the income of the future guestworkers before they left for Germany.

This pattern is often repeated. Guestworkers tend to come from somewhere in the middle part of the occupational structure, not the very bottom, because the poorest workers cannot afford the cost of travel or the risk that a job might fall through. For that reason guestworker programs are more complicated to assess, because they typically do not attract the most vulnerable workers. The guests often have some options, but whether the options are sufficient is the crucial question.

Survey results give us a clue to the answer. According to Paine, three-quarters of the Turkish guests cited financial difficulties as their primary motive for migrating. ${ }^{30}$ Many had debts to repay or were unable to save anything out of their current wages. Despite being better off than the typical Turk, many of the guests did not seem to have enough or possess sufficiency before accepting the German offer. They were therefore exploitable, although most could not be described as desperate.

But were the Turkish guestworkers also exploited? Did they receive less than a Turk with enough would be willing to take? Some no doubt did, but a large share of the Turkish guestworkers were well compensated. The German unions insisted that guestworkers be paid as much as German workers in comparable jobs, which were chiefly in construction and industry. ${ }^{31}$ In Paine's survey the average wage was actually $10 \%$ less than native Germans earned in these sectors. ${ }^{32}$ But living expenses were relatively low, hence the guests could save much of their income. Paine reports that the typical guestworker earned four times more than before departure, and six times as much as the typical Turkish worker who remained at home. ${ }^{33}$ Their German wages vaulted many guests to the top strata of the domestic Turkish income scale. The typical guestworker was saving each year the equivalent of two years of take-home pay for the average domestic worker. This is why the

30. Paine, Exporting Workers, pp. 200, 87-88.

31. On union protection for guestworkers see James Hollifield, Immigrants, Markets, and States: The Political Economy of Postwar Europe (Cambridge, MA: Harvard University Press, 1992), pp. 59-60; and Stephen Castles and Godula Kosack, Immigrant Workers and Class Structure in Western Europe (Oxford: Oxford University Press, 1985), p. 129.

32. Paine, Exporting Workers p. 99.

33. Ibid., p. 100. 
waiting list for prospective Turkish guestworkers stretched years into the future.

More than half of the Turkish guestworkers appear to have earned well above the sufficiency level in their native land. But deductions from their earnings must be made for the low quality of the work, the costs of family separation, the difficult living conditions, and the discrimination Turks experienced in Germany. ${ }^{34}$ These factors would influence the decision of a worker in the home country who begins with enough. Given this discount, the share of Turkish guestworkers which we would judge to be exploited grows, but for a goodly number the level of compensation was sufficiently high and thus not exploitative. Certainly the Germans were in a position to exploit their guests, and no doubt some unscrupulous employers did. But union protection prevented wholesale exploitation of the guestworkers, and the high level of compensation seems to have rendered the exchange acceptable for many. In Paine's survey onehalf of the Turkish guests reported satisfaction with the experience, and many stayed in Germany year after year. ${ }^{35}$

Although Walzer depicts the German case as paradigmatically exploitative, closer attention to the level of compensation suggests that the Gastarbeiter program was, at least with regard to compensation, a model which other nations should imitate. The pay for many guestworkers was good and sufficiently high to avoid eroding the wages of German unskilled workers. ${ }^{36}$ At the very least one can say that there are much worse cases of guestworker exploitation than the German program of the 1960s. ${ }^{37}$

34. On the human costs of guestwork in Germany see Herbert, History of Foreign Labor, pp. 218-20, 225-28.

35. Paine, Exporting Workers, p. 98.

36. Turkish guestworkers in Germany benefited from the relatively compressed wage scale, which paid blue-collar workers only a little less than the median income. A median income in Germany was a very high income in Turkey. In the United States, by contrast, income inequality is much greater and unskilled guests will therefore earn well below the median income. See Philip Martin, Guestworker Programs: Lessons from Europe (Washington: U.S. Department of Labor, 1980), p. 39.

37. After the Gastarbeiter program was terminated in 1973, Germany did not expel its large guest population. Assimilation and naturalization of these immigrants proceeded slowly, but many analysts offer a positive assessment of this subsequent chapter in the German guestworker story. Even without German citizenship, the Turkish guests won many of the rights enjoyed by ethnic Germans. See Yasemin Soysal, Limits of Citizenship: Migrants and Postnational Membership in Europe (Chicago: University of Chicago Press, 1994); David Jacobson, Rights across Borders: Immigration and the Decline of Citizenship (Baltimore: Johns Hopkins Press, 1996); and Christian Joppke, "The Legal-Domestic Sources of Immigrant Rights: The United States, Germany, and the European Union," Comparative Political Studies 34 (2001): 339-66. 
A case in point is the Bracero program established by the United States during the Second World War. ${ }^{38}$ This program recruited Mexican workers on temporary contracts, chiefly for agricultural labor. Most braceros did stoop work, picking cotton or lettuce or grapes during the harvest season. Back-breaking work like this rarely attracts anyone who has enough, so the recruits are almost certainly exploitable. According to Jaime Storey, the typical bracero was "on the upper level of the very poorest sectors of the population." ${ }^{39}$ Many were landless day-laborers, underemployed in Mexico and living near the level of subsistence. Their options were quite poor, and this put them at a severe disadvantage in bargaining with the Americans.

By Mexican standards, however, the American farmers paid excellent wages. Even after deductions for room, board, and insurance, the braceros often earned more than ten times the typical Mexican farm wage. ${ }^{40} \mathrm{~A}$ guestworker could return from a 90-day contract with hundreds of dollars in savings, the equivalent of two or three years of subsistence in rural Mexico. Typically, some of the savings would be invested in housing or tools or land, or used to set up a small business. A bracero who found steady work during his short stay in the United States, and who was not cheated by his employers, could return to his village with considerably more money than a merchant or skilled craftsman might make in a year.

But not all braceros were this lucky. Some did not find steady work, and others were cheated by unscrupulous employers. Deductions for room and board could often be unreasonable, and the wages paid were frequently below the hourly rate for American farm workers - a practice that was illegal but rarely punished. The living conditions were spartan, at best, and the work was certainly dirty and difficult. ${ }^{41}$ Although many returning guests reported sat-

38. On the history of temporary worker recruitment programs in the United States see Vernon Briggs, "Nonimmigrant Labor Policy: Future Trend or Aberration?" in The Unavoidable Issue: U.S. Immigration Policy in the 1980s, ed. Demetrios Papademetrious and Mark Miller (Philadelphia: Institute for the Study of Human Issues, 1983), pp. 93-122. On the Bracero program see Ernesto Galarza, Strangers in Our Fields (Washington: Fund for the Republic, 1956); Ernesto Galarza, Merchants of Labor: The Mexican Bracero Story (Charlotte: McNally \& Loftin, 1964); and Kitty Calavita, Inside the State: The Bracero Program, Immigration, and the I.N.S. (New York: Routledge, 1992).

39. Jaime Storey, "The Braceros" in Uprooted: Braceros in the Hermanos Mayo Lens, ed. Jaime Storey and John Mraz (Houston: Arte Público Press, 1996), p. 43.

40. See the figures cited in Galarza, Strangers in Our Fields, pp. 2-3, 30, 36; and Michael Belshaw, A Village Economy: Land and People of Huecorio (New York: Columbia University Press, 1967), pp. 124-33, 324-25.

41. For accounts of these abuses see Galarza, Strangers in Our Fields and Merchants of Labor. 
isfaction with the experience, others said that in el norte "one is not free because one is a slave of work." ${ }^{42}$

These factors are a discount on the wages earned from guestwork and would certainly affect the calculation of a Mexican who began with a sufficiency income. Knowing the costs of agricultural guestwork, would an individual already at the level of sufficiency still make the journey? It seems unlikely, as several empirical studies demonstrate. Michael Belshaw offers an in-depth portrait of one Mexican community from which braceros were recruited in A Village Economy. ${ }^{43}$ Scarcely anyone in the village earned a sufficiency wage, and the few who did never became braceros. Richard Hancock also reports that landowners in Chihuahua rarely traveled north, even when their plots were small, because a farm of one's own was so highly prized. And though a bracero could earn more than some middle-class Mexicans, none of the latter would dream of doing stoop work for the Americans. ${ }^{44}$ The discount on the wages was very steep. Only someone without enough would accept an offer on these terms.

We might therefore conclude that the Bracero program was exploitative for the great majority of the Mexican guests. They earned less than someone with enough would find acceptable. American farmers and consumers gained at the expense of these workers, who were not paid a sufficiency wage for the hard work they did. Because the discount is so high, agricultural guestworker programs will almost invariably be exploitative. ${ }^{45}$

By comparing the Gastarbeiter and Bracero programs we can identify six factors that increase the likelihood of exploitation in guestworker arrangements: first, if the work is agricultural rather than industrial ${ }^{46}$ second, if guests are paid less than the prevailing

42. Belshaw, $A$ Village Economy, p. 126. Belshaw includes a series of first hand accounts in his chapter on the braceros, pp. 123-33.

43. See the chapter on the labor force in Belshaw, $A$ Village Economy, pp. 96-155.

44. Richard Hancock, The Role of the Bracero in the Economic and Cultural Dynamics of Mexico: A Case Study of Chihuahua (Stanford: Hispanic American Society, 1959), pp. 105, 124.

45. On the plight of agricultural guestworkers see Alec Wilkinson, Big Sugar: Seasons in the Cane Fields of Florida (New York: Knopf, 1989); M. L. Hall, "Defending the Rights of H-2A Farmworkers," North Carolina Journal of International Law and Commercial Regulation 27/3 (2002): 521-37; and Laura Oliveira, "A License to Exploit: The Need to Reform the H-2A Temporary Agricultural Guest Worker Program," The Scholar: St. Mary's Law Review on Minority Issues 5 (2002): 153-78.

46. Guestworkers who do domestic labor also tend to experience harsh exploitation. On the plight of female domestic guestworkers see Rhacel Parrenas, Servants of Globalization: Women, Migration, and Domestic Work (Stanford: Stanford University Press, 2001); Christine Chen, In Service and Servitude: Foreign Female 
wage in the host nation; third, if income inequality in the host nation is large; fourth, if a host nation does not have to compete with neighbors to recruit guests, ${ }^{47}$ fifth, if enforcement of contract provisions by the host government is lax; and sixth, if the discount factor is high due to harsh living conditions, abuse, or bigotry in the host country. With regard to the sixth item the United States may have been no worse than West Germany, but America surely scored worse on the first five. The Bracero program was for these reasons more thoroughly exploitative than the Gastarbeiter system. The disadvantageous position of the Mexican guests was overdetermined.

Unfortunately, it seems that many of these conditions persist as the United States contemplates establishing a new guestworker program for unskilled labor. True, many of America's twenty-first century guestworkers will be employed in factories or service sector jobs, not on the farm. But it is also true that they will not make much more than the minimum wage, which is well below a living wage for domestic workers. We also have good reason to fear that oversight of employers will continue to be lax. It therefore seems doubtful that someone with enough in labor-exporting nations like Mexico would take these unskilled jobs at the wages being offered, especially if the status is only temporary. Many immigrants put up with low wages and bad work when they first arrive in order to become American citizens. But if that prize is not available, this temporary opportunity will only seem advantageous to one who does not already have enough.

\section{Acceptable Exploitation}

All three theories of exploitation considered in this article would judge the Bracero program to be exploitative. But they do so for different reasons. For Walzer the unfairness was the refusal to set the Mexican hands on the path to American citizenship. For Attas the unfairness was the restriction of these guestworkers to specific jobs or employers. But according to the sufficiency standard the unfairness lay in the inadequate level of remuneration, which was less than someone with enough would accept. These exploitable workers did

Domestic Workers and the Malaysian "Modernity" Project (New York: Columbia University Press, 1998); Nicole Constable, Maid to Order in Hong Kong: Stories of Filipina Workers (Ithaca: Cornell University Press, 1997); and Daniel Bell, "Equal Rights for Foreign Resident Workers?" Dissent 48/4 (2001): 26-34.

47. One reason why the Gastarbeiter program was less exploitative was that West Germany had to compete with other European nations for guestworkers. On this point see Hahamovitch, "Creating Perfect Immigrants," p. 85. 
not gain as much as a Mexican at the level of sufficiency would have found acceptable. But if the level of compensation had been higher, the loss of freedom of occupation or citizenship would not have mattered. The workers would have made enough to compensate them for the sacrifices guestworker status entails. They would have become identical to highly skilled guests, who are not exploited.

Once we have decided that an offer is exploitative, however, the task of assessment is not finished. We have established that the offer is unfair, but next we must consider how unfair it is. ${ }^{48}$ If the unfairness is modest, and the transaction produces significantly better consequences for the disadvantaged party than the likely alternative, we ought to tolerate the exploitation as a lesser evil. Prohibiting the exchange will do more harm than good, especially for the one who is vulnerable. Sometimes exploitation is the lesser evil.

This problem only arises because exploitative offers tend to be mutually advantageous. Both parties gain by trading. The gains are not proportionate, but a lesser gain for the disadvantaged party may yield much more utility than the cheap gain for the exploiter, precisely because the one who is exploited starts with less. The exploiter can take it or leave it, but the exploitable agent really needs the gain. For that reason we have to think twice about blocking the exchange. It may be preferable to permit the injustice in order to improve the situation of the exploited party. Indeed, Alan Wertheimer argues that "we start from the presumption that a mutually advantageous and consensual agreement should be permitted," even when it is exploitative, precisely because the moral force of exploitation claims is relatively low. ${ }^{49}$

We can think of acceptable exploitation as the "dirty hands" problem in just-price theory. We tolerate an injustice for the sake of the good consequences that result. In just war theory dirty hands are only permissible in cases of emergency, when the survival of a people is at risk. ${ }^{50}$ But the stakes in economic exchanges are much lower. One rarely exploits out of necessity, and the prospective guests are rarely so desperate as to have no other choice. The host country is not forced to get its hands dirty; it chooses to do so. Such choices are impermissible when innocent lives are at stake, but economic exploitation is usually a much less dirty business. It does not kill, and in fact it can make its victims better off than if they are not exploited at all.

48. Wertheimer, Exploitation, pp. 278-309.

49. Ibid., p. 296.

50. Michael Walzer, Just and Unjust Wars: A Moral Argument with Historical Illustrations (New York: Basic Books, 1977), pp. 251-68. 
In recognizing the dirty-hands problem in mutually advantageous transactions, however, we must avoid giving host nations or employers a license to exploit foreign labor mercilessly. There are limits to acceptable exploitation, and they must be clearly specified. I hold that taking unfair advantage of others is permissible only if (1) the exploitation is modest, not severe, and (2) this exploitation significantly enhances the well-being of the exploited party compared to the most likely clean-hands alternative.

With regard to the first condition, how do we know that the exploitation is modest? The sufficiency threshold provides the answer. If the discounted level of compensation approaches the amount that an agent with enough would accept, the exploitation is modest. Many bracero guestworkers probably fell in this category. As noted in the previous section, a temporary Mexican farmhand in the 1950s could often earn ten or twelve times more than a daylaborer who remained at home. But with the discount for family separation, bigotry, and back-breaking work, this high wage was probably still too low to attract Mexicans who started at the level of sufficiency. Still, it was not a slave wage. If the host employers paid the prevailing wage of American farmhands, as the law mandated, and did not cheat or abuse their braceros, the exploitation was likely modest, not severe. The biggest problem with the Bracero program was that too many employers paid less than the prevailing wage or cheated their guests in other ways. ${ }^{51}$ The rules were broken and oversight was lax, and these abuses increased the level of exploitation experienced by many braceros unacceptably. Unless the United States improves its oversight mechanisms, we have reason to fear that a new guestworker program will frequently violate this first condition of acceptable exploitation. ${ }^{52}$

51. One might be justifiably pessimistic that the United States could avoid perpetrating these abuses again, in which case it ought not to establish a guestworker program. But Hahamovitch argues that the abuses were restricted during the first five years of the Bracero program: "Despite sporadic and sometimes serious mistreatment on American farms, this five-year period was one of the few times in the history of guestworker programs when foreign workers were treated somewhat like guests." However, the abuses grew worse in later years. See Hahamovitch, "Creating Perfect Immigrants," p. 82.

52. As Vernon Briggs points out, an enforcement mechanism that relies on guestworker complaints to detect abuse will be ineffective because guestworkers often remain silent in order to avoid employer retaliation. See Briggs, "Nonimmigrant Labor Policy," p. 115. See also Michael Holley, "Disadvantaged by Design: How the Law Inhibits Agricultural Guest Workers from Enforcing Their Rights," Hofstra Labor Law Journal 18 (2001): 575-623. 
The best way to ensure that the level of exploitation is only modest, not severe, is to insist that wages for domestic and foreign workers be identical and not so low as to undercut the standard of living of native unskilled labor. The Gastarbeiter program is the model which other host nations should imitate. There should be equal pay for equal work, regardless of citizenship, and the pay ought to approach a living wage in the host country. With remuneration set at that level, and the rules conscientiously enforced, exploitation will be minimized or perhaps even abolished.

But there is a second condition that must be met before a host government may dirty its hands. When faced with several feasible policy options, it should choose the one that reduces deprivation the most. Sometimes this is the dirty-hands option.

There are two basic ways to avoid exploiting guestworkers and thus to keep our hands clean. The first is to increase the level of legal immigration into the country, setting all who enter the domestic labor force on the path to naturalization. Because the newcomers are not guests, they do not experience guestworker exploitation. The alternative clean-hands policy is to keep the newcomers out, so that they are neither guests nor (legal or illegal) immigrants. Because exploitation is an injustice of exchanges, if we refuse to exchange with these outsiders, we cannot exploit them. The second option, then, is to reduce immigration.

These clean-hands alternatives are not equally feasible in the United States and other nations today, and they impact the disadvantaged in very different ways. Increasing immigration beyond current levels will reduce the deprivation of the most disadvantaged, who live abroad, but that policy is opposed by both political parties and a large majority of the electorate. Keeping outsiders out is the more popular alternative today, but it increases deprivation for the most disadvantaged. ${ }^{53}$ If we insist on clean hands, then, the option most likely to be chosen is the one that worsens the plight of would-be guests. When this is so, I hold that it is preferable to import guestworkers, even when the program is (modestly) exploitative, because this dirty-hands option will reduce deprivation for those who are more disadvantaged than the clean-hands policy of exclusion.

An underlying assumption of this argument is a qualified cosmopolitan principle that requires national communities to weigh

53. On the benefit of increased immigration for the world's poor see Howard Chang, "Liberalized Immigration as Free Trade: Economic Welfare and the Optimal Immigration Policy," University of Pennsylvania Law Review, 145 (1997): 1147-1244. 
the impact of immigration policies on outsiders. ${ }^{54}$ This principle does not demand that we dismantle national borders or redistribute resources on a global scale. But it does prohibit communities from choosing policies that increase deprivation abroad in order to benefit those at home who start with more. Regardless of their citizenship status, the disadvantaged have some claims against those who enjoy sufficiency. Relieving their deprivation should be prioritized.

Opponents of guestworker programs frequently have a different priority. They focus on the plight of domestic unskilled labor, which may be worsened by guestworker programs..$^{55}$ Many economists agree that the gains from increased immigration are not evenly distributed: while businesses and consumers benefit from an influx of cheap labor, some unskilled workers will face increased competition. The group most likely to lose is the previous wave of immigrants, who still do unskilled work. ${ }^{56}$ They pay disproportionately for the benefits of increased immigration. Taxpayers may pay a cost, too, if unskilled immigrants bring their families and settle down. The cost of government benefits for these families may exceed their contribution to the economy. ${ }^{57}$ An influx of cheap labor may also retard technological innovation in the industries that rely on guestworkers,

54. For a strong version of the cosmopolitan assumption in liberal egalitarian theory see Joseph Carens, "Aliens and Citizens: The Case for Open Borders," Review of Politics 49 (1987): 251-75. For a more moderate version, which I endorse, see Howard Chang, "Liberal Ideals and Political Feasibility: Guestworker Programs as Second-Best Policies," North Carolina Journal of International Law and Commercial Regulation 27 (2002): 465-81.

55. For excellent criticisms of the guestworker concept that emphasize the cost to domestic unskilled labor see Philip Martin and Michael Teitelbaum, "The Mirage of Mexican Guest Workers," Foreign Affairs 80/6 (2001): 117-31; and U.S. Commission on Immigration Reform, Becoming an American: Immigration and Immigrant Policy (Washington, D.C.: USCIR, 1997), pp. 109-110.

56. On the impact of guestworker programs on domestic unskilled labor see Barry Chiswick, "The Impact of Immigration on the Level and Distribution of Economic Well-Being," in The Gateway: U.S. Immigration Issues and Policies, ed. Barry Chiswick (Washington: American Enterprise Institute, 1982), p. 310; Julian Simon, The Economic Consequences of Immigration (Ann Arbor: University of Michigan Press, 1999), pp. 242, 266; Peter Stalker, Workers without Frontiers: The Impact of Globalization on International Migration (Boulder: Lynne Rienner Publishers, 2000), p. 87; and Howard Chang, "Economic Analysis of Immigration Law," in Migration Theory: Talking across Disciplines, ed. Caroline Brettell and James Hollifield (New York: Routledge, 2000), p. 210.

57. On the cost to taxpayers if unskilled immigrants are quickly naturalized see Chang, "Liberal Ideals and Political Feasibility," pp. 466-467; Chang, "Economic Analysis of Immigration Law," p. 215; Chiswick, "The Impact of Immigration on the Level and Distribution of Economic Well-Being," p. 310; and Stephen Kershnar, "Immigrants and Welfare," Public Affairs Quarterly 16/1 (2002): 39-61. 
and consumers will pay for this in the long run. Domestically, the biggest beneficiaries of these programs are the employers who hire guestworkers and profit from their labor. And these employers, of course, hardly count as disadvantaged.

But to reject guestworker programs on these grounds discounts the plight of would-be guests, who are typically worse off than domestic unskilled workers. Like host employers and consumers, the guests will benefit if they are admitted, and their benefit should be prioritized. Even if the program is modestly exploitative, that option is preferable to the clean-hands policy of exclusion, which avoids the taint of exploitation but leaves the would-be guests worse off than if they are admitted.

As Cindy Hahamovitch observes, guestworker programs historically are the product of "an uncomfortable marriage between those who desired and those who resented foreign workers." ${ }^{58}$ If foreign workers are admitted as guests, neither camp gets its preferred option, but both also avoid their worst outcome. To be sure, the compromise has frequently resulted in the exploitation of foreign labor. But as long as the exploitation is not severe, that option is preferable to exclusion. Hahamovitch notes that sometimes the guestworker option has "staved off ... more draconian immigration restrictions by promising that state power could be employed to make immigration temporary." Draconian immigration restrictions constitute a nonexploitative option, and when that is the likely alternative to a guestworker program, modest exploitation is the lesser evil. ${ }^{59}$

\section{Conclusion}

Given America's past record, there is good reason to fear that a new guestworker program will result in exploitation. Host employers and consumers may well gain at the expense of their guests, but not for the reasons identified by egalitarian and neoclassical exploitation theory. The root cause of exploitation is insufficiency, which motivates the disadvantaged to accept less than one who

58. Hahamovitch, "Creating Perfect Immigrants," p. 78.

59. Ibid., p. 76. Indeed, those with a cosmopolitan sensibility should be especially receptive to guestworker programs when they cannot enact their preferred policy of increased immigration. This is because temporary guests often become permanent residents. Once admitted, it is difficult for democratic states to expel these workers. Guestworkers, then, are often backdoor immigrants and future citizens or their legal equivalent. As the advocates of exclusion have come to recognize, "there is nothing more permanent than temporary workers." See Martin and Teitelbaum, "The Mirage of Mexican Guest Workers," p. 131. 
has enough would settle for. If this is correct, we might expect the next wave of American guestworkers to earn less than the just price for their labor. They will not be paid a sufficiency wage. And if Bracero-like abuses are tolerated, the exploitation will be unacceptably severe.

But if the pay is decent and the abuses are minimized, the exploitation may only be modest. Modest exploitation is still unfair, but given the feasible alternatives it may be the best policy choice if we prioritize the interests of those who are badly off. When the public prefers restricting immigration, it blocks exploitation at home but increases deprivation abroad. The clean hands worsen the plight of those who are especially vulnerable. When that prospect looms, tolerating exploitation is preferable as long as it is restricted. True, this exploitation is wrong. But washing our hands of those who begin without enough is the greater injustice, because the refusal to exchange is sometimes worse than taking advantage.

This argument justifies an injustice-the injustice of exploitation. Exploitation is a problem of commutative justice, which is concerned with bilateral transactions between agents who are formally equal. I am arguing that sometimes it is right to tolerate wrong in these transactions; some exploiters should be allowed to take unfair advantage of those who are vulnerable. The justification may seem to be consequentialist, focusing on benefits rather than justice, but the appearance is deceptive. I am not saying, with Machiavelli, that if the act accuses, the result excuses. Rather, I am arguing that exploitation is in certain cases a lesser wrong than another commutative injustice-the refusal to exchange-and it is more consistent with a higher principle of distributive justice, giving priority to those who start without enough. Consequences, then, do not trump justice in this argument. Rather, some principles of justice are given priority over others and lesser injustices are preferred to greater ones when perfect justice is not feasible. It is wrong to exploit, but it is worse to neglect if this increases deprivation for the disadvantaged party.

This is not the type of justification for guestworker programs which the Bush administration would welcome. It does not acknowledge the dirty-hands dilemma or the exploitation its admission policy will likely facilitate. But the opponents of guestworker exploitation are sometimes even more blind. They see the wrong of exploitation but not the greater evil of deprivation, which guestworker programs may reduce. Their hands are not really clean but just soiled in a different way. The truly clean hands option is to expand immigration, guarantee a living wage to all, and redistribute 
resources across borders in a more equitable fashion. But hardly anyone favors that option, and it would be wrong to impose it against the will of the majority. So policy in this arena must settle for a principle of minimizing dirt. A decent guestworker program best matches that principle. 